\title{
Penyelesaian Sengketa dalam Pengadaan Tanah Bagi Pembangunan Jalan untuk Kepentingan Umum
}

\author{
Fengky Kotalewala ${ }^{1^{*}}$, Adonia Ivone Laturette ${ }^{2}$, Novyta Uktolseja ${ }^{3}$ \\ 1, 2, ${ }^{3}$ Fakultas Hukum Universitas Pattimura, Ambon, Indonesia \\ *E-mail:frankbmaru@gmail.com
}

Dikirim: 18/02/2020

\begin{tabular}{l}
\hline Info Artikel \\
\hline Keywords: \\
Dispute Resolution; \\
Land Acquisition; \\
Public Interest. \\
\\
\\
Kata Kunci: \\
Penyelesaian \\
Sengketa; Pengadaan \\
Tanah; Kepentingan \\
umum.
\end{tabular}

Aanstract classic problem that always creates turmoil in the community. This study aims to analyze land acquisition followed by land acquisition belonging to the people, always causing disputes that sometimes lead to violence or at least lead to court. The research method used normative research with a statute approach and a conceptual approach and analyzed descriptive qualitative. Based on the Research Results, it is indicated that Settlement of disputes in Land Procurement for Road Development in the public interest should be carried out to the maximum extent possible through consultation and / or through non-litigation or settlement outside the Court. Land Procurement for Development for public purposes, give Honor to holders Land Rights by providing legal protection and by providing fair and appropriate compensation to the rightful parties, but in reality often the holders of the rights granted experience a decline in quality compared to the original situation before the release of land rights.

\begin{tabular}{l}
\hline Abstrak \\
Pengadaan tanah bagi Pembangunan jalan Untuk Kepentingan Umum \\
merupakan masalah klasik yang senantiasa memunculkan gejolak \\
dimasyarakat Penelitian ini bertujuan untuk menganalisis pengadaan \\
tanah yang diikuti dengan pembebasan lahan milik rakyat selalu \\
menimbulkan perselisihan yang kadang berujung kekerasan atau \\
setidaknya bermuara ke pengadilan. Metode penelitian menggunakan \\
penelitian normatif dengan pendekatan perundang-undangan (statute \\
approach) dan pendekatan konseptual (conceptual approach) serta \\
dianalisis secara deskriptif kualitatif. Berdasarkan hasil penelitian \\
menunjukan penyelesaian sengketa dalam pengadaan tanah bagi \\
pembangunan jalan untuk kepentingan umum hendaknya dilakukan \\
semaksimal mungkin melalui musyawarah dan/atau melalui jalur non \\
litigasi atau penyelesaian diluar pengadilan. Pengadaan tanah bagi \\
pembangunan untuk kepentingan umum memberikan penghormatan \\
terhadap pemegang hak atas tanah dengan memberikan perlindungan \\
hukum dan dengan memberikan ganti kerugian yang adil dan layak
\end{tabular}


DOI:

10.47268/sasi.v26i3.397 kepada pihak yang berhak, akan tetapi kenyataannya seringkali pemegang hak atas yang memberikan haknya mengalami penurunan kualitas dibandingkan keadaannya semula sebelum pelepasan hak atas tanah.

\section{A. PENDAHULUAN}

Hubungan manusia dengan tanah yang kuat menuntut jaminan perlindungan hukum agar manusia dapat melaksanakan hak-haknya secara aman. ${ }^{1}$ Keberadaan kehidupan masyarakat dengan tanah merupakan suatu hubungan antara tanah dan penguasanya, dalam hal ini adalah masyarakat hukum adat, dalam kehidupan sehari-hari menjalankan aktifitas mereka berdasarkan aturan dan norma yang berbeda-beda sesuai dengan adat tradisi yang dianut oleh masing-masing masyarakt hukum adat yang terpencar pencar di seluruh belahan jiwa bangsa Indonesia Tanah juga berdampak pada pemerintah yang dalam hal ini pemerintah mempunyai kewenangan untuk menguasai tanah di pergunakan dan diperuntukan pada masyarakat tapi kenyataan yang terjadi masyarakat banyak di rugikan oleh pemerintah. ${ }^{2}$ Tanah sebagai faktor produksi yang utama dalam masyarakat, haruslah diletakkan dibawah kekuasaan negara. Karena tanah mempunyai fungsi yang sangat strategis, baik sebagai sumber daya alam maupun sebagai ruang untuk pembangunan.

Negara mempunyai hak terhadap tanah yang disebut hak untuk menguasai, sebagaimana diterangkan dalam Pasal 33 ayat (3) Undang-Undang Dasar Negara Republik Indonesia 1945 yang telah diamandemen (Selanjutnya disebut UUD NRI 1945) yang berbunyi : "bumi, air, dan kekayaan alam yang terkandung didalamnya dikuasai oleh negara dan dipergunakan untuk sebesar-besarnya bagi kemakmuran rakyat”.

Negara selaku badan penguasa akan dapat senantiasa mengendalikan atau mengarahkan pengelolaan fungsi bumi, air dan ruang angkasa serta kekayaan alam yang terkandung didalamnya sesuai dengan peraturan dan kebijakan yang ada, yaitu dalam lingkup penguasaan secara yuridis yang beraspek publik. ${ }^{3}$ Di dalam kerangka peningkatan kesejahteraan rakyat dan menunjukkan keadilan sosial, maka reforma agraria menjadi pijakan kebijakan yang penting dalam kepastian hukum mengenai kepemilikan tanah untuk masyarakat. ${ }^{4}$

Tujuan hak menguasai oleh negara atas sumber daya alam khususnya tanah ialah keadilan sosial dan sebesar-besarnya kemakmuran rakyat. Tanah tidak boleh menjadi alat kekuasaan negara. Tanah tidak boleh menjadi alat kekuasaan perseorangan untuk menindas dan memeras hidup orang lain. Kepemilikan tanah merupakan sebuah hak asasi yang dilindungi oleh hukum internasional maupun hukum nasional. Hukum Tanah Nasional sebagaimana diatur dalam UUPA, membedakan antara hak-hak pengusaan atas tanah dengan hak-hak atas tanah. Hak-hak penguasaan atas tanah adalah hak-hak yang masing-masing

1 Hetharie, Y. (2019), "Perjanjian Nominee sebagai Sarana Penguasaan Hak Milik atas Tanah oleh Warga Negara Asing Menurut Kitab Undang-Undang Hukum Perdata”, SASI, 25 (1): 27-36, h. 27.

2 Uktolseja, N dan Radjawane, P. (2019), “Tinjauan Juridis Perkembangan Tanah-Tanah Adat (Dahulu, Kini dan Akan Datang)", SASI, 25 (1): 13-26, h. 25, h. 25.

3 Bakri, M. (2007), Hak Menguasai Tanah Oleh Negara (Paradigma Baru Untuk Reformasi Agraria), Yogyakarta: Citra Media, h. 5.

${ }^{4}$ Saija, R., Letsoin, F. X. R. V., Akyuwen, R. J., \& Radjawane, P. (2020), "Status Kepemilikan Hak atas Tanah Adat Marga dalam Kebijakan Penataan Aset Reforma Agraria di Kabupaten Maluku Tenggara", SASI, 26 (1): 99-100, h. 107.

$$
416 \text { |S A S I Vol. } 26 \text { No.3, Juli - September } 2020
$$


berisikan kewenangan, tugas/kewajiban dan/atau larangan bagi pemegang haknya untuk berbuat sesuatu dengan bidang tanah yang dimilikinya. Terkait kepemilikan atas tanah, Undang-Undang Republik Indonesia Nomor 5 Tahun 1960 Tentang Peraturan Dasar PokokPokok Agraria (Selanjutnya disebut UUPA) juga menyatakan dengan tegas tentang hak individu kepemilikan hak atas tanah. Meski demikian tanah juga memiliki fungsi sosial. Berkaitan dengan fungsi tanah, Pasal 6 UUPA menegaskan bahwa walaupun manusia dengan tanah bersifat abadi selaku pemilik tanah, tidak berarti pemilik tanah boleh semena-mena menggunakan haknya, tanpa memperhatikan kepentingan orang lain.

Kebutuhan akan tersedianya tanah untuk keperluan pembangunan tersebut memberi peluang terjadinya pengambil alihan tanah untuk berbagai proyek, baik untuk kepentingan negara/kepentingan umum maupun untuk kepentingan bisnis, dalam skala besar maupun kecil..$^{5}$ Implikasi dari adanya kepentingan inilah maka biasanya penguasa mempergunakan kekuasaan untuk menekan pihak yang lemah yakni masyarakat hukum adat sebagai penguasa dan pemilik sumber daya agraria/tanah di wilayah ulayatnya. ${ }^{6}$

Konteks pengadaan tanah untuk pembangunan bagi kepentingaan umum, hak milik atas tanah bisa dicabut justru karena tanah memiliki fungsi sosial. Pengadaan tanah yang diperuntukkan kepentingan umum oleh pemerintah dilaksanakan dengan pelepasan ataupun pembebasan hak atas tanah. Selain itu pengadaan tanah juga dilakukan dengan cara jual beli, tukar-menukar, atau pun dengan cara lain yang disepakati. Penerbitan berbagai ketentuan perundang-undangan bidang pertanahan sejatinya dimaksudkan untuk adanya ketertiban dalam penguasaan tanah, namun dalam kenyataannya menunjukkan adanya perselisihan atau persengketaan.

Pasal 6 Undang-Undang Republik Indonesia Nomor 5 Tahun 1960 Tentang Peraturan Dasar Pokok-Pokok Agraria bahwa: "semua hak atas tanah mempunyai fungsi sosial". Artinya bahwa tanah tidak hanya diatur dan dikelola oleh negara namun dimanfaatkan untuk kesejahteraan seluruh masyarakat. ${ }^{7}$ Negara memiliki kekuasaan atas tanah dalam arti negara mempunyai kewenangan untuk mengatur semua hubungan atas tanah agar berbagai dimensi kebutuhan masyarakat secara perorangan maupun kelompok dapat terpenuhi. Kemudian pada Pasal 18 Undang-Undang Republik Indonesia Nomor 5 Tahun 1960 Tentang Peraturan Dasar Pokok-Pokok Agraria dijelaskan bahwa "untuk kepentingan umum, termasuk kepentingan bangsa dan negara serta kepentingan bersama dari rakyat, hak-hak atas tanah dapat dicabut, dengan memberi ganti kerugian yang layak dan menurut cara yang diatur dengan undang-undang.

Sehubungan dengan itu pula diterbitkan berbagai ketentuan perundangan yang memberikan kewenangan kepada penyelenggara pemerintahan untuk menyelesaikan sengketa tersebut, di samping melalui lembaga pengadilan. Berdasarkan Pasal 2 UndangUndang Nomor 5 Tahun 1960 tentang Peraturan Dasar Pokok-Pokok Agraria bahwa urusan pertanahan merupakan urusan pemerintahan yang diselenggarakan oleh Pemerintah,karena itu pula penyelesaian sengketa pertanahan merupakan kewenangan Pemerintah.

Hal ini dipertegas lagi dalam Peraturan Presiden Nomor 20 Tahun 2015 tentang Badan Pertanahan Nasional (Selanjutnya disebut BPN), yang secara tegas menyebutkan bahwa

5 Kasenda, D. GG. (2015). “Ganti Rugi Dalam Pengadaan Tanah Untuk Kepentingan Umum”, Jurnal Morality, 2 (2): Tanpa Halaman.

6 Matuankotta, J. K. (2020), "Pengakuan dan Perlindungan Hukum Terhadap Eksistensi Pemerintahan Adat", SASI, 26 (2): 188-200, h.193.

7 Limbong, B. (2015). Pengadaan Tanah untuk Pembangunan Fasilitas Umum, Cetakan ke III, Jakarta Selatan: Margareta Pustaka, h. 13. 
BPN sebagai lembaga pemerintah non departemen mempunyai tugas melaksanakan tugas pemerintah di bidang pertanahan secara nasional, regional dan sektoral. Lebih lanjut disebutkan bahwa untuk melaksanakan tugas tersebut BPN menyelenggarakan fungsi, yang meliputi 14 bidang, yang salah satunya adalah penanganan dan penyelesaian sengketa pertanahan. Namun demikian berdasarkan Keputusan Presiden Nomor 34 Tahun 2003 tentang Kebijakan Nasional dibidang Pertanahan, yang menyebutkan bahwa sebagian kewenangan pemerintah dibidang pertanahan dilaksanakan oleh pemerintah daerah kabupaten/kota yang antara lain meliputi urusan penyelesaian sengketa pertanahan tertentu.

Pembebasan atau pelepasan hak atas tanah adalah pelepasan hubungan hukum antara seseorang dengan tanah yang dimilikinya dengan cara pemberian ganti rugi yang besarnya didasarkan atas pada musyawarah antara kedua pihak. Sedangkan pencabutan hak atas tanah adalah pengambilan tanah secara paksa oleh negara atas tanah milik seseorang yang mengakibatkan hak atas tanah itu menjadi hapus. Kegiatan perolehan tanah untuk kepentingan umum sering di kenal dengan istilah "Pengadaan Tanah" dengan menggunakan dasar hukum Undang-Undang Republik Indonesia Nomor 2 Tahun 2012 tentang Pengadaan Tanah Bagi Pembangunan Untuk Kepentingan Umum, dalam Pasal 1 ayat (9) UndangUndang (Selajutnya disebut UU). No. 2 tahun 2012 Tentang Pengadaan Tanah Bagi Pembangunan untuk Kepentingan Umum menyebutkan bahwa pelepasan hak atas tanah adalah kegiatan pemutusan hubungan hukum dari pihak yang berhak kepada negara melalui lembaga pertanahan. Pencabutan, pembebasan, dan pelepasan hak-hak atas tanah tidak hanya dilakukan oleh pemerintah untuk pembangunan berbagai proyek pemerintah, namun juga diperuntukkan untuk bagi proyek pembangunan untuk kepentingan umum oleh pihak swasta tetapi pelaksanaanya dilakukan dalam bentuk dan cara yang berbeda.

Ada berbagai masalah yang sering timbul dalam proses pengadaan tanah, baik itu masalah status hak yang tidak jelas. Begitu juga dengan bentuk dan besarnya ganti kerugian yang akan diberikan kepada masyarakat yang terkena dampak, dalam konteks pengadaan tanah bagi pelaksanaan pembangunan untuk kepentingan umum, banyak persoalan juga muncul akibat kelemahan regulasi. Disatu sisi, pembuat regulasi dalam hal ini Pemerintah dan Dewan Perwakilan Rakyat (Selanjutnya disebut DPR) memang sudah menerbitkan UU Nomor 2 tahun 2012 Tentang Pengadaan Tanah Bagi Pembangunan Untuk Kepentingan Umum. Di sisi lain aspek material dari semua regulasi yang ada, kurang memadai sehingga berpotensi menimbulkan sengketa. Beberapa faktor yang berpotensi menimbulkan sengketa tersebut, antara lain: definisi dan cakupan kepentingan umum. Mekanisme pengadaan tanah, bentuk dan dasar perhitungan ganti rugi, serta penerapan sistem konsinyasi (penetapan uang ganti rugi ke pengadilan). ${ }^{8}$

Pemberian Ganti Rugi Pengadaan Tanah Untuk Kepentingan Umum sering menjadi masalah dan merupakan penghambat pengadaan tanah karena pemberian ganti rugi dianggap terlalu rendah dan dianggap tidak dapat menjamin kesejahteraan kehidupan lebih lanjut. Apalagi penilaian harga ganti rugi didasari perhitungan Nilai Jual Objek Pajak (Selanjutnya disebut NJOP) terhadap tanah yang akan dijadikan objek pembangunan adalah relatif sangat rendah dan tidak sesuai dengan harga yang berlaku dipasar.

Penilaian harga berdasarkan NJOP lah sering manjadi masalah utama dalam proses pengadaan tanah untuk pembangunan bagi kepentingan umum, Sedangkan pada prinsipnya, pengadaan tanah untuk kepentingan umum adalah pembebasan tanah yang bersifat memaksa (compulsory land acquisition $)^{9}$, dimana pemerintah dapat membebaskan tanah dari si

8 Hartanto, A. (2015). Panduan Lengkap Hukum Praktis: Kepemilikan Tanah, Jakarta: Penerbit Laksbang Justitia, h. 19.

9 Ibid, h. 20. 
pemilik tanah meskipun si pemilik tidak berkeinginan untuk menjual tanah tersebut. Namun, berdasarkan asas keadilan, meskipun pengadaan tanah tersebut bersifat memaksa, namun ganti kerugian yang diberikan kepada pemilik tanah tidak boleh mengakibatkan penurunan taraf kehidupan sebelum dilakukannya pengadaan tanah tersebut.

Demikian halnya kerapkali pembangunan infrastruktur jalan mengalami hambatan dalam pembangunan bagi kepentingan umum. Salah satu hambatan yang paling rumit dihadapi adalah kegiatan perolehan tanah yang dijadikan sebagai lahan pembangunan baik itu untuk maksud pembangunan jalan baru, pelebaran jalan maupun penataan pada kawasan ruang milik jalan, padahal didalam UU Nomor 38 Tahun 2004 tentang jalan telah mengatur bagian-bagian jalan meliputi ruang manfaat jalan, ruang milik jalan dan ruang pengawasan jalan. Dimana pada ruang manfaat jalan / rumaja meliputi badan jalan, tepi saluran jalan dan ambang pengamannya, sedangkan ruang milik jalan/rumija meliputi ruang manfaat jalan dan sejalur tanah tertentu diruang manfaat jalan, serta ruang pengawasan jalan/ruwasja merupakan ruang tertentu diluar ruang milik jalan yang ada dibawah pengawasan penyelenggara jalan.

Pengaturan ini merupakan suatu upaya untuk mewujudkan asas penyelenggaraan jalan baik itu asas kemanfaaatan, keamanan dan keselamatan jalan, maka pemerintah mengeluarkan "Kebijakan Jalan Yang Berkeselamatan "sebagai upaya mewujudkan jalan yang berkeselamatan. Salah satu permasalahan yang penulis angkat pada penelitian ini penyelesaian sengketa dalam pengadaan tanah untuk pembangunan jalan bagi kepentingan umum, sebagai contoh berlokus di kawasan Underpass Jalan Sudirman di Desa Batu Merah Kota Ambon.

Berdasarkan dalam rencana stategis dan rencana kerja kementerian Pekerjaan Umum dan Perumahan Rakyat, dalam hal ini Balai Pelaksana Jalan Nasional XVI Ambon (Selajutnya disebut BPJN XVI Ambon) di tahun Anggaran 2017 telah mengalokasikan anggaran untuk paket pembangunan jalan Underpass Sudirman, akan tetapi dalam pelaksanaannya pembangunan Underpass mengalami hambatan dimana pihak yang berhak atas objek pengadaan tanah tidak bersedia melepaskan hak atas tanahnya dan hal ini sangat berdampak bagi keseluruhan pembangunan jembatan merah putih dan pembangunan Underpass sudirman sebagai bagian utuh dari rencana kerja dan rencana strategis Kementerian Pekerjaaan Umum dan Perumahan Rakyat (Selanjutnya disebut PUPR), dalam hal memberikan jasa pelayanan transportasi yang nyaman, lancar dan berkeselamatan demi kepentingan umum yang lebih luas.

Pengadaan lahan pada wilayah pembangunan jalan kini masih bermasalah dimana ganti rugi dalam pengadaan tanah ini menjadi sumber konflik antara pemilik hak / rakyat dan pemerintah, dalam hal ini pemerintah sebagai penguasa yang diberikan hak menguasai negara adalah tidak jarang menggunakan konsinyasi dalam memaksakan kehendak kepada masyarakat untuk melepaskan haknya.

\section{B. METODE PENELITIAN}

Metode yang digunakan dalam jurnal ilmiah ini adalah yuridis normatif yaitu penelitian hukum yang dilakukan dengan cara meneliti bahan pustaka atau bahan hukum sekunder sebagai bahan dasar untuk diteliti dengan cara mengadakan penelusuran terhadap peraturan dan literatur yang berkaitan dengan permasalahan yang diteliti. ${ }^{10}$ Bahan hukum yang ada kemudian dianalisis secara kualitatif untuk menarik kesimpulan guna menjawab

10 Soekanto S, dan Mamudji, Sri. (2001). Penelitian Hukum Normatif (Suatu Tinjauan Singkat), Jakarta : Rajawali Pers, h. $13-14$. 
permasalahan yang dikaji.

\section{PEMBAHASAN}

\section{Faktor-Faktor Penyebab Terjadi Masalah dalam Pengadaan Tanah Bagi Pembangunan Untuk Kepentingan Umum}

Pengadaan Tanah untuk pembangunan kepentingan umum di Indonesia merupakan masalah klasik yang sering memunculkan gejolak dimasyarakat. Bahkan dalam sejumlah kasus, pengadaan tanah yang diikuti pembebasan lahan milik rakyat selalu menimbulkan perselisihan yang berujung kekerasan atau setidaknya bermuara ke pengadilan. Perselisihan dalam pembebasan lahan itu pada dasarnya memang disebabakan perbedaan yang tajam soal ganti untung pengadaan tanah itu sendiri. Disatu pihak pemerintah menilai bahwa kompensasi yang diberikan kepada masyarakat sudah sesuai dengan ketentuan yang berlaku.

Penyelenggaraan pengadaan tanah untuk kepentingan umum memperhatikan keseimbangan antara kepentingan pembangunan dan kepentingan masyarakat, dilaksanakan dengan pemberian Ganti Kerugian yang layak dan adil ${ }^{11}$. Ketidaksesuaian ini berkaitan dengan esensi layak dan adil yang memiliki unsur penggantian untuk upaya pemulihan korban terdampak, baik bersifat material dan imaterial agar mampu bangkit dan terpenuhi hak asasinya. ${ }^{12}$

Dilain pihak, masyarakat yang terkena pembebasan merasa ganti untung yang diberikan tidak adil. Bila ditilik sepintas, masalah yang menjadi penyebab sengketa ada dalam pengadaan tanah sepertinya hanya menyangkut faktor-faktor hukum. Namun, bila dipelajari lebih jauh, untuk memenuhi unsur keadilan dalam pengadaan tanah, hukum hanyalah satu dari beberapa segi penting pengadaan tanah untuk pembangunan kepentingan umum. Faktor hukum hanya memecahkan masalah pengadaan tanah dari segi hukum dan peraturan-peraturan yang diberlakukan dan dikembangkan. Kaca mata hukum terbukti tidak cukup memadai untuk mengatasi masalah pengadaan tanah walaupun peraturan perundangan-undangan terus disempurnakan.

Faktor-faktor yang mempengaruhi dalam pengadaan tanah untuk pembangunan kepentingan umum, antara lain: ${ }^{13}$

a) Faktor Pengadaan Tanah dari Segi Hukum.

Sebelum penerbitan UU nomor 2 tahun 2012 yang diikuti pula dengan dikeluarkannya Perpres 71 tahun 2012, sudah ada beberapa produk yang mengatur pertanahan dan pengadaan tanah. Produk pertama yang diterbitkan adalah UU nomor 5 tahun 1960 tentang Peraturan Dasar Pokok-Pokok Agraria, yang kerap disebut sebagai UUPA saja. Lahirnya UUPA ini terutama didorong oleh semangat mengganti UU Agraria produk pemerintahan jajahan, yakni Agrarische Wet (Staatsblad 1870 Nomor 55) dengan semua peraturan turunnya. Intinya UUPA mengatur peruntukan dan penggunaan, mengatur dan menetapkan hubungan-hubungan hukum warga negara dengan tanah, air dan ruang angkasa diseluruh wilayah Indonesia.

11 Subekti, R. (2016), "Kebijakan Pemberian Ganti Kerugian dalam Pengadaan Tanah Bagi Pembangunan untuk Kepentingan Umum”, Yustisia, 5 (2): 376-394, h. 387.

12 Suntoro, A. (2019), "Penilaian Ganti Kerugian Dalam Pengadaan Tanah untuk Kepentingan Umum:

Perspektif HAM", BHUMI: Jurnal Agraria dan Pertanahan, 5 (1): 13-25, DOI: http://dx.doi.org/10.31292/jb.v5i1.316, h. 13.

13 Marsoem, S. Cs, (2015). Pedoman Lengkap Ganti Untung Pengadaan Tanah, Jakarta: Penerbit Renebook, h. 47-69. 
Dengan lahirnya UUPA ini masalah-masalah dasar yang menyangkut politik hukum agrarian bisa dibilang sudah selesai, apalagi diikuti dengan penerbitan UU nomor 20 tahun 1961, yang berisi tentang Pencabutan Hak-Hak Atas Tanah dan Benda-Benda yang ada diatasnya. UU ini memungkinkan negara mencabut hak-hak warga negara atas tanah yang telah diatur dalam UUPA, dengan kompenasasi yang layak apabila negara memerlukannya. Selain kompensasi yang layak, pencabutan itu pun mensyaratkan persetujuan presiden.

Selama kurang lebih satu dasawarsa, semua upaya pengadaan tanah untuk tujuan pembangunan mengacu pada UU tersebut. Meski demikian dalam tahap operasional masih diperlukan peraturan-peraturan yang mengatur pelaksanaannnya secara lebih terperinci. Diawal era Orde Baru, tuntutan akan pengadaan tanah untuk pembangunan yang dicanangkan pemerintah semakin meningkat. Intensitas pengadaan tanah yang tinggi untuk pembangunan kepentingan umum rupanya tidak cukup hanya berbekal kedua UU tersebut. Dalam prakteknya, pelaksanaan pengadaan tanah kerap menimbulkan konflik karena perbedaan pandangan tentang "Kepentingan Umum" dari kaca mata versi rakyat dan dari kaca mata proyek pembangunan.

Dengan berbagai perbedaan pandangan yang kerap terasa cukup tajam itu, tuntutan ikhwal kejelasam "Kriteria Kepentingan Umum" dirasa makin mendesak. Atas dasar itulah, pemerintah kemudian mengeluarkan Instruksi Presiden (Selanjutnya disebut Inpres) nomor 9 Tahun 1973. Disitu dirumuskan dengan jelas jenis-jenis kegiatan yang dapat digolongkan sebagai kepentingan umum. Sampai dengan di keluarkanya Inpres tersebut, masalah tata cara pengadaan tanah untuk kepentingan umum masih mengacu pada UU nomor 20 tahun 1961.

Sebagai bentuk pelaksanaan UU di tingkat operasional, pemerintah mengeluarkan Peraturan Dalam Negeri (Selanjutnya disebut Permendagri) Nomor 15 tahun 1975 yang mengatur ketentuan-ketentuan tentang tata cara pengadaan tanah. Permendagri ini melengkapi prosedur pencabutan hak atas tanah seperti diatur dalam UU Nomor 20 Tahun 1961 dengan prosedur pengadaan tanah untuk kepentingan umum, tetapi memperkenalkan istilah " Pengadaan Tanah ". Pengadaan Tanah yang diartikan sebagai pelepasan hak atas tanah baru dapat dilakukan setelah ada kesepakatan tentang ganti rugi atas dasar musyawarah antara pemegang hak atas tanah dengan pihak yang membutuhkan tanah tersebut.

Selama hampir dua dasawarsa Permendgri ini menjadi acuan bagi upaya pengadaan tanah untuk pembangunan. Selama itu masih ditemukan banyak masalah yang menunjukan kelemahan perangkat hukum tersebut baik secara yurids maupun kenyataan dilapangan, misalnya pemilik tanah menolak pengadaan tanahnya, sedangkan instrument hukum yang ada belum mengatur masalah seperti ini, maka Pemerintah menerbitkan Keputusan Presiden (Selanjutnya disebut Keppres) Nomor 55 Tahun 1993. Keppres ini menggunakan istilah "Pelepasan atau Penyerahan Hak Atas Tanah" yang prinsipnya bermakna sama dengan istilah pengadaan tanah.

Didalam peraturan pengganti ini istilah Pencabutan Hak Atas Tanah sebagai jalan penyelesaian masalah pengadaan tanah untuk pembangunan tidak digunakan lagi, karena yang ditonjolkan adalah prinsip musyawarah mufakat dalam kesepakatan tentang ganti rugi. Keppres ini menutup kekurangan atau kelemahan Permendagri, khususnya mengenai pihakpihak yang boleh melakukan pengadaan tanah dan perhitungan ganti rugi yang didasarkan harga dasar. Lebih jauh juga, Keppres ini juga memuat batasan-batasan dan bidang-bidang peruntukan bagi kepentingan umum sebagai dasar pengadaan tanah. Lebih rinci lagi, Keppres Nomor 55 Tahun 1993 memuat aturan tersendiri tentang tata cara pengadaan tanah terbagi menjadi dua, yaitu :

a) Pelepasan hak atau Penyerahan hak atas tanah, 
b) Cara jual-beli, tukar-menukar, atau cara lain yang disepakati oleh pemilik tanah dengan pihak yang memerlukan tanah.

Cara pertama hanya berlaku bagi pengadaan tanah yang peruntukannya bagi kepentingan umum. Sedangkan cara yang kedua khusus untuk pengadaan tanah guna kepentingan lain yang bukan kepentingan umum. Setelah era reformasi, pemerintah focus mempercepat pembangunan, dengan mengambil kebijakan mempercepat proses pengadaan tanah bagi pelaksanaan pembangunan dengan menerbitkan Perpres Nomor 36 Tahun 2005 tentang Pengadaan Tanah Bagi Pelaksanaan Pembangunan Untuk Kepentingan Umum, yang pada prinsipnya isi Perpres yang disahkan mei 2005 ini sama dengan Keppres Nomor 55 Tahun 1993. Hanya ada sedikit perbedaan istilah bahwa dalam peraturan yang baru istilah Pencabutan Hak Atas Tanah kembali digunakan.

Selanjutnya pengadaan tanah diluar kepentingan umum yang dilaksanakan pemerintah, pemerintah daerah atau pihak swasta, diatur dengan cara jual-beli, tukar-menukar, atau dengan cara lain yang disepakati secara sukarela dengan pihak-pihak yang bersangkutan. Namun keluarnya Perpres justru menimbulkan protes dimana-mana karena dianggap mengakomodir kepentingan terselubung. Masyarakat menilai, peraturan baru ini bukan untuk memperjuangkan kepentingan umum, melainkan kepentingan kelompok tertentu, dan akhirnya pemerintah mengambil keputusan mengubah dan menyempunakan Perpres Nomor 36 Tahun 2005. Selanjutnya di ganti dengan Perpres Nomor 65 Tahun 2006, yang isinya memberi penjelasan yang lebih terperinci mengenai prinsip musyawarah dalam pengadaan tanah. Malah dalam, peraturan terakhir ini tampak kian memberi tekanan yakni, bila warga tidak menerima kompensasi dalam bentuk ganti rugi yang diberikan pemerintah untuk proyek kepentingan umum, maka uang ganti rugi akan dititipkan ke pengadilan (Konsinyasi) untuk kemudian dilakukan pencabutan hak atas tanah warga. Namun, ada perkembangan menarik dari Perpres Nomor 65 tahun 2006 terkait aspek prosedural. Pertama adalah proses Konsinyasi, baik untuk uji legalitas kualifikasi suatu proyek pembangunan untuk kepentingan umum atau keabsahan prosedural pelaksanaan praktik pengadaan tanah di masyarakat.

Belakangan diketahui, soal konsinyasi ini menjadi persoalan hukum karena istilah ini tidak dikenal dalam pengurusan belanja negara. Karena pengeluaran negara menggunakan bukti yang sah, benar dan jelas peruntukannya. Bukti penitipan uang ke pengadilan bukan bukti yang benar dan bertentangan dengan mekanisme pelaksanaan pembayaran atas beban APBN. Jika kita teliti dari sisi instrument hukum masalah pengadaan tanah bisa dibilang sudah sedemikian terperinci, akan tetapi dalam pelaksanaan dilapangan ternyata masih menimbulkan gesekan. Secara umum, gesekan muncul akan ketika pengadaan tanah sampai pada tahap pembicaraan tentang ganti rugi. Pada tahap ini, menimbulkan perbedaan pandangan tentang nilai ganti rugi antara masyarakat pemilik tanah dengan panitia pengadaan tanah. Umumnya dengan mengikuti petunjuk pelaksanaan yang dikeluarkan Pemerintah Daerah, panitia pengadaan secara faktual menggunakan "Nilai Jual Objek Pajak" (Selanjutnya disebut NJOP) sebagai patokan atau dasar perhitungan nilai ganti rugi.

Sementara masyarakat pemilik tanah menuntut nilai ganti rugi sesuai dengan atau lebih tinggi dari harga pasaran. Bila dicermati, penetapan NJOP menjadi dasar perhitungan nilai ganti rugi pengadaan tanah sesungguhnya melanggar peraturan perundangan tentang NJOP itu sendiri, sebab dari pihak perpajakan sendiri menyatakan dasar kebijakan dan yuridisnya bahwa NJOP semata-mata untuk tujuan perpajakan.

Sebagai contoh rujukan kebijakan pihak perpajakan adalah Surat Kepala Pelayanan Pajak Jakarta Selatan Nomor S-310/WPJ.04/KP.0906/2011, tanggal 7 Juni 2011, Perihal Data NJOP. Surat Kepala Pelayanan Pajak Jakarta Selatan itu dikeluarkan atas permintaan 
Kepala Dinas Perhubungan Provinsi DKI Jakarta tentang Konfirmasi NJOP di lokasi yang berkaitan dengan pengadaan tanah untuk proyek Mass Rapid Transit (MRT) di Jakarta Selatan. Pada bagian akhir surat tersebut dinyatakan "Perlu disampaikan bahwa berdasarkan Pasal 6 UU Nomor 12 Tahun 1985, sebagaimana telah diubah dengan UU Nomor 12 Tahun 1994, NJOP yang ditetapkan Menteri Keuangan adalah untuk tujuan perpajakan.

Dengan demikian, penggunaan NJOP diluar tujuan perpajakan bukan menjadi tanggung jawab Direktorat Jenderal Pajak." itu sebabnya, kebijakan penggunaan NJOP sebagai basis kompensasi pengadaan tanah boleh dibilang merupakan bentuk penyimpangan dari tujuan utamanya, yakni semata mata untuk tujuan perpajakan. Secara faktual, penyimpangan ini berpotensi melahirkan kejahatan struktural dan pelanggaran hak asasi para pemilik tanah. Dari prespektif manajemen kinerja proyek, kondisi ini amat rentan berdampak destruksi modal social para pemiik tanah dan membuka ruang terjadi konflik pengadaan tanah dalam konteks kebijakan pengadaan tanah proyek pembangunan infarstruktur.

Secara lebih luas, kondisi seperti ini berdampak terhadap pelanggaran hak ekonomi, sosial, dan budaya para pemilik tanah. Lebih jauh lagi, hal ini juga menimbulkan trauma psikososial berkepanjangan dikalangan masyarakat "korban" pengadaan tanah. Dari beragam masalah yang masih menggelayuti upaya pengadaan tanah untuk kepentingan umum, terutama berkaitan dengan kompensasi, memperlihatkan bahwa instrument hukum yang masih ada mengandung kelemahan. Apalagi dalam upaya pemerintah mempercepat pembangunan infrastruktur guna meningkatkan perekonomian, masalah yang ada seputar pengadaan tanah terasa cukup mengganjal.

Inilah yang mendorong lahirnya aturan baru yang isinya menyempurnakan semua instrument hukum tentang pengadaan tanah yang ada selama ini. Aturan baru ini dituangkan dalam hierarkhi yang lebih tinggi berbentuk Undang-Undang, yakni, UU Nomor 2 tahun 2012 yang khusus mengatur Pengadaan Tanah Untuk Kepentingan Umum. Aturan pelaksanaanya pun menyusul dalam bentuk Perpres Nomor 71 Tahun 2012. Kedua Instrumen hukum baru yang mulai berlaku pada awal tahun 2015 ini dengan masa persiapan selang 2013-2014 menawarkan solusi atas masalah-masalah yang muncul dalam penerapan peraturan-peraturan sebelumnya. Perubahan mendasar dalam instumen yang baru ini adalah tidak digunakan lagi dasar NJOP sebagai dasar perhitungan pengadaan tanah.

Selain itu dalam aturan ini mengamanatkan agar pengadaan tanah untuk kepentingan umum dilaksanakan dengan pemberian ganti kerugian yang layak dan adil. Pihak yang berhak dan Pihak yang menguasai objek pengadaan wajib mematuhi ketentuan dalam undang-undang ini.

b) Faktor Pengadaan Tanah dari Segi Psikososial

Dari berbagai kajian yang dilakukan, diperoleh fakta bahwa masalah tanah bukan sekedar menyangkut ikatan atau hubungan hukum antara pemilik dan tanahnya. Bahkan yang lebih mendasar lagi persoalan persoalan tanah tidak lepas dari masalah hak asasi seperti tercantum dalam Pasal $28 \mathrm{H}$ ayat 4 UUD NRI 1945. Lebih jauh lagi, masalah pertanahan menyisahkan problematic psikososial ditengah masyarakat yang hingga kini justru belum tersentuh, bahkan lepas dari perhatian pemerintah. Padahal, masalah pengadaan tanah tidak bisa dibilang selesai seiring dengan selasainya masalah kompensasi yang telah disepakati bersama. Pemberian kompensasi baru menyelesaikan dimensi hukum pengadaan saja tetapi belum menyentuh penyelesaian aspek-aspek hak asasi, seperti ekonomi,sosial dan kultural "korban" pengadaan tanah, setelah mereka mengalami perpindahan ke lokasi yang baru.

Secara faktual, di era Reformasi dan Keterbukaan ini sering terjadi kasus individu 
atau masyarakat yang tanahnya pernah dibebaskan dengan alasan kepentingan umum kini menggugat atau mempersoalkan kembali ganti rugi yang pernah diterimanya. Akibatnya pembangunan infrastruktur sering terhambat persoalan pengadaan tanah, bahkan tidak terselesaikan tuntas, terutama apabila tidak ada kesepakatan tentang ganti rugi. Karena itu diharapkan Pelepasan atau Penyerahan hak atas tanah harus mengakomodasi prinsip-prinsip penghargaan terhadap hak dasar manusia, antara lain hak untuk sejahteradan hidup layak. Namun kenyataannya, setelah urusan pengadaan tanah selesai, kesejahteraan sosial-ekonomi masyarakat yang mengorbankan tanahnya untuk kegiatan pembangunan tidak diperhatikan. Tidak jarang terjadi, pasca pelepasan hak atas tanah, dengan diterimanya ganti rugi atau kompensasi dan telah diserahkannya hak atas kepada pihak yang memerlukan kehidupan social-ekonomi masyarakat justru lebih buruk. Apalagi umumnya yang terkena dampak pelepasan hak atas tanah adalah masyarakat golongan bawah dengan tingkat pendidikan minimum dan tinggal dikawasan perdesaan atau pinggiran. Dan seolah-olah pemerintah lepas tangan dan masyarakat terkesan dibiarkan untuk mencari solusi sendiri.

Berdasarkan studi Bahar menemukan gambaran mengenai masalah transparansi, keterbukaan dan keikutsertaan masyarkat dalam menyusun tata ruang. Disatu sisi dengan mengetahui rencana tata ruang wilayah akan meminimalisasi praktek percaloan, spekulasi dan praktek kolusi dan korupsi. Disisi lain akan dapat meningkatkan kesejahteraan masyakat yang terkena dampak pengadaan tanah sejak awal mereka telah mengetahui tingkat harga tanah didaerahnya, dengan demikian jika harga tanah menjadi tinggi keuntungannya akan dinikmati pemilik tanah secara langsung tanpa dinikmati para spekulan atau calo. Termasuk sejak awal pemilik tanah sudah dapat mengatisipasi dan mempersiapkan diri terhadap dampak yag akan timbul dan akan menatap masa depan yang pasti.

Selama ini keterbukaan informasi dan kejelasan tata ruang ini selalu diabaikan dalam proses negosiasi pengadaan tanah dengan pemilik tanah. Sementara pendekatan pembangunan kita di era reformasi ini masih memberi kesan represif, kekerasan dan rentan pemaksaan. Kebijakan ini menempatkan masyarakat atau rakyat jelata tak berdaya dan menjadi korban. Dampaknya bukan saja berwujud kekerasan dan kerusakan lingkungan alam serta komunitas manusia secara umum tetapi juga terutama terhadap modal sosial, alam, dan budaya komunitas masyarakat adat/local yang terkena proyek pembangunan.

Konflik dan kekerasan memecah-belah masyarakat dengan meruntuhkan rasa percaya secara interpersonal dan komunal (interpersonal and communal trust). Lebih jauh lagi, konflik dan kekerasan membinasakan norma-norma dan nilai-nilai yang mendasari kerjasama dan tindakan kolektif untuk kemanfaatan bersama (common good), dan meningkatkan kemungkinan perselisihan dan perpecahan. Komunal. Konflik dan kekerasan merusak pula modal social dan kohesi social masyarakat korban pengadaan tanah. Disisi lain dampak trauma psikososial yang masuk dalam katagori modal kognitif menunjukan setidaknya dua isu startegis.

Pertama, Penolakan terhadap sebutan "warga korban proyek pembangunan" . Penolakan itu itu disebabakan oleh fakta bahwa kehidupan mereka ternyata lebih buruk sedangkan harga tanah pengganti terlau mahal dan tidak bisa dibeli dengan uang kompenasassi yang diterima.

Kedua, warga korban proyek pembangunan merasakan pengalaman traumatis, dimana akses ekonomi semakin susah setelah pengadaaan tanah karena uang kompensasi habis ditengah jalan. Situasi seperti ini dipengaruhi antara lain: untuk mendapatkan tanah pengganti membutuhkan waktu, sementara harga-harga tanah terus melambung selama mereka mencari tanah pengganti yang sesuai. Berdasarkan pengalaman membuktikan banyak warga yang lebih susah termasuk harus menjadi pengontrak setelah mereka pindah 
dan tinggal di lokasi pengganti.

c) Faktor Pengadaan Tanah dari Segi Penilai ${ }^{14}$.

Setelah pemerintah menegaskan UU Nomor 2 Tahun 2012, yang disusul dengan Perpres Nomor 71 Tahun 2012, fungsi lembaga atau tim penilai dalam proses pengadaan tanah makin lebih jelas dan tegas. Demikian pula tata cara dan manajemen pengadaan tanah untuk pembangunan kepentingan umum lebih mendetail, dan memberikan kewenangan yang lebih besar kepada penilai untuk menghitung besaran ganti kerugian hingga ke hal-hal non fisik. Dimana dalam UU Nomor 2 Tahun 2012 dan dengan berlakunya Perpres Nomor 71 tahun 2012 memberikan peran yang lebih besar kepada lembaga atau tim penilai indepeden tetapi juga melahirkan sejumlah persoalan tersendiri. Yang mana Kementerian Agraria dan Tata Ruang sebagai instansi pemerintah juga beri peran dalam pengadaan tanah cukup sering menggelar pelatihan untuk para penilai anggota Masyarakat Profesi Penilai Indonesia ( Selanjutnya disebut MAPPI) sebagai satu-satunya asosiasi penilai yang diakui di Indonesia.

Dimana melalui forum ini para penilai memperoleh pedomaan yang jelas tentang penilai dalam rangka pengadaan tanah bagi pelaksanaan pembangunan untuk kepentingan umum adalah penilaian untuk pemberian kompensasi yang meliputi ganti rugi fisik dan non fisik. Yang fisik terdiri atas ganti rugi nilai bidang tanah, nilai bangunan, tanaman, dan benda-benda lain yang berkaitan dengan tanah yang memilik fungsi dan posisi yang tetap dan tidak dapat dipindahkan, serta merupakan bagian yang tidak terpisahkan dari bangunan. Sementara ganti rugi non fisik, meliputi nilai kehilangan usaha atau bisnis, nilai kehilangan akses terhadap sumber daya atau mata pencarian, dan nilai ekonomi lingkungan yang dibayarkan kepada negara untuk relokasi kawasan dan/ atau pemulihan kerusakan lingkungan yang diakibatkan oleh pengadaan tanah.

Tetapi agak disayangkan bahwa setelah BPN mendapat peran lebih besar lagi dalam pengadaan tanah sebagaimana diatur dalam UU Nomor 2 Tahun 2012, Badan Pemerintah ini tidak segera memberikan pelatihan-pelatihan kepada para penilai, terutama bagi mereka yang belum memiliki kualifikasi, kompentensi, dan pengalaman cukup dalam kegiatan penilaian. Baru pada tahun 2014 ini bersama dengan MAPPI melakukan sosialisasi UU Nomor 2 Tahun 2012 sekaligus Deseminasi SPI 306.

BPN menerbitkan lisensi kepada penilai dan lembaga penilai untuk pelaksanaan pekerjaan penilaian ganti kerugian yang sekarang berlaku nasional. Pada awalnya disyaratkan atau diberikan catatan komitmen terhadap kapasitas penilai ganti rugi ini adalah selain telah mengikuti pendidikan/pelatihan yang diselenggarakan oleh BPN juga disyaratkan minimal pendidikan S2, namun saat ini tampaknya hal tersebut tidak berlanjut kembali. Seperti diketahui, keanggotaan MAPPI sendiri, sesungguhnya memiliki empat jenjang.

a) keanggotaan dengan katagori MAPPI-A, yakni perseorangan yang tertarik pada bidang penilaian dan belum memiliki kualifikasi, kompentensi dan pengalaman serta memenuhi semua persyaratan sebagaimana ditetapkan dalam Anggaran Rumah Tangga MAPPI.

b) anggota dengan katagori MAPPI-P yakni mereka yang tertarik dan/ atau bekerja di bidang penilaian atau bidang yang terkait langsung dengan kegiatan penilaian.

c) anggota dengan katagori MAPPI-T, yakni mereka yang berprofesi dan bekerja dibidang penilaian atau bidang yang terkait langsung dengan kegiatan penilaian dan memiliki kualifikasi, kompentensi dan pengalaman dalam kegiatan penilaian.

${ }^{14}$ Ibid, h. 69.

425 |S A S I Vol.26 No.3, Juli - September 2020 
d) Sebagai jenjang tertinggi dengan katagori keanggotaan MAPPI-S, terdapat mereka yang telah memiliki Sertifikat Penilai yang dikeluarkan dan /atau di sahkan oleh MAPPI. Penilai Bersertifikat akan diberi gelar MAPPI (Cert). Selain sebagai anggota MAPPI, penilai pertanahan sebutan untuk penilai publik yang melakukan kegiatan penilaian dalam rangka pengadaan tanah, harus memiliki izin penilai yang diterbitkan oleh Keementerian Keuangan serta lisensi dari BPN ( Kementerian Agraria dan Tata Ruang ) sebagai lembaga pelaksana pengadaan tanah.

Selain Faktor-Faktor tersebut diatat, terdapat faktor-faktor lain sebagai penyebab dalam mempengaruhi pengadaan tanah untuk kepentingan umum, yaitu: ${ }^{15}$

a) Perbedaan Motivasi Masing-Masing Pihak dalam Bekerjasama.

Perbedaan antara pihak pemerintah dengan lembaga penilai indepeden bisa muncul karena sejak awal motivasi masing-masing pihak tidak sama. Pemerintah menghendaki proses penilaian atas tanah berjalan cepat, dengan harga murah dan berjalan mudah tanpa ada protes dari warga disamping juga karena terkendala Tahun Anggaran dan ketersedian data administrasi yang cukup dari masing-masing bidang tanah yang akan dibebaskan. Sedangkan lembaga penilai indenpenden menginginkan proses penilaian sesuai prosedur, melakukan pemeriksaan dengan teliti sehingga membutuhkan waktu tidak sedikit, dan melakukan penilaian secara lengkap sehingga tidak merugikan pemilik tanah.

Perbedaan motivasi dari masing-masing pihak ini bisa diminimalkan apabila sejak awal merumuskan dalam nota kesepahaman, perencanaan yang baik yang berisi kesepakatan mengenai standar prosedur operasional yang baik, dan apabila ditengah jalan muncul persoalan, maka setiap pihak bersedia membangun komunikasi dan melakukan musyawarah.

b) Perbedaan Kapabilitas, Kompetensi dan Pemahaman dalam Menggarap Proyek.

Tidak selamanya kerjasama antara Pemerintah dan Lembaga Penilai Independen berjalan mulus karena kedua belah pihak memiliki perbedaan dalam kapabilitas, kompentensi dan pemahaman dalam pengadaan tanah untuk kepentingan umum. Ini terjadi apabila Pemerintah Daerah setempat baik ditingkat provinsi maupun kabupaten/kota, tidak memiliki pengalaman sebelumnya dalam pengadaan tanah. Sedangkan lembaga independen sebelumnya sudah memiliki pengalaman karena telah melakukan proses pengadaan tanah diprovinsi dan kabupaten lain.

Namun bisa pula terjadi kelangkaan atau bahkan tidak ada sama sekali tenaga lembaga penilai independen disuatu daerah, terutama didaerah terpencil dan pelosok. Kalaupun ada ada lembaga penilai independen, jumlahnya terbatas atau kapabilitas, kompetensi dan pengalamannya pun masih minim. Contohnya, saat lembaga peenilai independen masih harus menghadapi persoalan pengadaan tanah dimana ada hak ulayat yang dimiliki oleh masyarakat hukum adat. Secara otomatis, para pihak yang berproses itu harus belajar dan memahami hak ulayat masyarakat hukum adat atas tanah-tanah adat yang akan dibebaskan. Untuk itu referensi dan pengalaman pengadaan tanah atas tanah-tanah adat yang ada hak ulayatnya harus diinventarisir dan didokumentasikan.

c) Kualitas Data yang Berbeda Bahkan Tak Memadai.

Jika dokumen pertanahan lemah, baik karena belum adanya pendaftaran/pendataan atas tanah, tidak adanya penyimpanan yang baik, belum selesai dalam proses dan tidak

15 Ibid, h. 91.

426 | S A S I Vol.26 No.3, Juli - September 2020 
adanya administrasi yang baik sehingga terjadi duplikasi, maka proses pengadaan tanah berjalan terhambat. Lembaga penilai independen dan pemerintah tidak bisa melakukan pengadaan tanah karena harus mengurus dan memverifikasi status tanah itu dari awal, mengenai siapa pemiliknya, dimana batas-batasnya dan keabsahan suratsuratnya. Oleh sebab itu, terkait hak ulayat harus jelas identifikasi kepentingan masyarakat hukum adat yang berhak atas tanah tersebut. Kemudian untuk hak perorangan, harus ada kejelasan subjek dan objeknya. Selanjutnya, pentingnya dilakukan pendaftaran tanah ke BPN setempat untuk kemudian mendapatkan sertifikat hak atas tanah sesuai dengan statusnya. Dan apabila terjadi perpindahan hak kepemilikan atau peruntukan atas tanah tersebut, ada baiknya dicatatkan ke BPN.

d) Kelemahan dalam Koordinasi dan Kolaborasi.

Kerjasama dalam proyek infrastruktur yang mengharuskan adanya pengadaan tanah harus dilakukan secara sinergis. Kelemahan dalam koordinasi dan kolaborasi bisa terjadi antara pemerintah dan lembaga penilai independen dikarenakan masing-masing pihak berasal dari kondisi atau latar belakang sistim manajemen yang berbeda. Pemerintah lebih administrative dan birokratis, sedangkan lembaga penilai independen lebih dinamis, tanpa sekat dan mengedepankan efektifitas serta efisiensi. Oleh sebab itu masing-masing pihak harus membangun sinergitas melalui komunikasi yang baik, agar proses pengadaan tanah yang kadang dapat memakan waktu bertahun-yahun bisa berjalan lancar sesuai target dan jadwal yang telah ditentukan. Ketika sudah masuk dalam sebuah tim pengadaan tanah, maka masing-masing pihak harus membangun irama dan kultur kerja yang mengacu pada nilai-nilai manajemen modern, seperti kerjasama yang sinergis, pelayanan yang terbaik, focus pada target, eksekusi yang cermat, akuntabilitas, berintegritas dan menjunjung tinggi Good Coorporate Governance (GCG)

e) Perbedaan Pemahaman terhadap Unsur Regulasi.

Acap kali perbedaan dalam penafsiran suatu peraturan perundangan antara pihak pemerintah dan swasta menjadi kendala dalam pengadaan tanah. Yang sering terjadi adalah penguasaan dan perbedaan dalam menafsirkan pasal-pasal terkait dengan aspek besarnya kompensasi, penyelesaian sengketa pertanahan, dan prosedur serta eksekusi pencabutan hak atas tanah. Agar pihak pemerintah dan lembaga penilai independen satu kata, maka setiap perbedaan pemahaman harus cepat diselesaikan. Jika perlu, dalam setiap pengambilan keputusan terlebih dahulu mendengarkan keterangan pakar, ahli hukum dan merujuk pada pengalaman terbaik yang pernah dilakukan dalam menangani persoalan yang sama.

f) Ketimpangan Pemahaman dan Penguasaan Aspek Teknis dan Adminstrasi Proyek.

Setiap proyek infrastruktur memilik permasalahan yang berbeda-beda bobotnya. Banyak unsur yang mempengaruhinya baik dari luas tanah yang dibebaskan, status tanah, kepadatan warga yang mendiami atau pemilik yang menguasai tanah, munculnya spekulan tanah yang membuat harga melambung, hingga ketersedian data pertanahan yang akurat dan lengkap, dalam menghadapi berbagai permasalahan yang muncul dalam pengadaan tanah, sebaiknya tim yang dibentuk memiliki pemahaman aspek teknis dan penguasaan administrasi proyek yang baik. Salah satu solusi jika menghadapi persoalan itu adalah perlunya orang-orang berpengalaman untuk menanganinya. Banyak proyek infrastruktur yang terhambat oleh pengadaan tanah gara-gara ditangani oleh orang yang tidak memiliki pengalaman dalam proses pengadaan tanah. 
g) Kondisi Ekonomi, Sosial dan Kultural Masyarakat.

Keberhasilan pengadaan tanah tergantung pada banyak aspek, terutama kondisi ekonomi, sosial dan kultural masyarakat. Pengadaan tanah diwilayah perkotaan atau padat penduduk dengan kegiatan ekonomi yang tinggi akan menuntut biaya ganti rugi yang tinggi, aspek penilaian harga tanah dan kompensasi yang rumit dan pendekatan atau kesepakatan dengan warga perkotaan dengan latar belakang yang heterogen. Kemudian jika pengadaan tanah terjadi diwilayah pedalaman atau pedesaan, tentu akan banyak menghadapi kepentingan masyarakat hukum adat terkait tanah-tanah hak ulayat. Di Indonesia yang terdiri banyak suku bangsa dan adat istiadat yang beragam, tentu membutuhkan pendekatan, pemahaman dan penyesuaian yang berbeda-beda sesuai dengan kondisi ekonomi, social, dan kultural masyarakat. Banyak kebijakan dan langkah pengadaan tanah gagal serta memicu konflik berkepanjangan karena pendekatan yang dipakai berbenturan dengan hukum adat yang dianut oleh masyarakat lokal.

h) Adanya Benturan Kepentingan.

Setiap pengadaan tanah melibatkan banyak pihak, seperti pemerintah, investor swasta, kontraktor proyek, konsultan, lembaga penilai tanah, hingga masyarakat pemilik tanah. Jika setiap pihak yang terlibat memiliki motif yang berbeda-beda atau agenda tersembunyi terhadap proyek, maka benturan kepentingan akan muncul. Benturan kepentingan akan semakin meruncing jika masing-masing pihak tidak bersedia melakukan penyesuaian untuk mencapai kesepakatan. Yang sering terjadi adalah pemerintah dan investor swasta menghendaki rendahnya nilai kompensasi. Sebaliknya, pemilik tanah menilai tanahnya adalah asset berharga yang nilainya tinggi sehingga akan berupaya untuk meminta kompensasi setinggi mungkin. Konflik kepentingan yang berbeda-beda ini dapat diselesaikan dengan berbagai cara, dari musyawarah untuk mencapai mufakat hingga menyelesaikan sengketa melalui putusan pengadilan. Masing-masing cara penyelesaian memerlukan waktu dan ongkos yang tidak sama. Agar perbedaan kepentingan bisa diminimalisir, maka ada sejumlah langkah yang perlu dilakukan antara lain:

1) Aturan yang jelas dan tidak memihak;

2) Adanya transparansi kebijakan pengadaan tanah;

3) Infrastruktur benar-benar untuk kepentingan umum;

4) Penilaian atas tanah yang adil dan tidak merugikan pemilik tanah;

5) Melibatkan semua pihak dalam setiap pengambilan keputusan sehingga mengurangi kecurigaan dan meningkatkan kerelaan masing-masing pihak.

\section{Penyelesaian Sengketa Ganti Rugi dalam Pengadaan Tanah Bagi Pembangunan Jalan Untuk Kepentingan Umum}

\section{a. Penyelesaian Sengketa Melalui Musyawarah Dalam Penetapan Ganti Rugi}

Penyelesaian sengketa dalam pengadaan tanah untuk kepentingan ditempuh melalui musyawarah antara instansi yang memerlukan tanah dan pihak yang berhak, gugatan, atau keberatan kepada pengadilan ${ }^{16}$. Penyelesaian sengketa tanah diperlukan kerjasama antara pemerintah dan masyarakat adat di dalam menyelesaiakan sengketa hak atas adat yang terjadi dapat diselesaikan dengan baik sehingga dapat memberikan rasa keadilan bagi

16 Santoso, U. (2016), "Penyelesaian Sengketa dalam Pengadaan Tanah untuk Kepentingan Umum", PERSPEKTIF, XXI (3): 188-198, h. 188. 
masyarakat adat, ${ }^{17}$ dengan demikian lembaga yang ditunjuk untuk menilai dan melakukan penaksiran terhadap harga objek pengadaan tanah harus dapat bersifat independent tidak berpihak pada salah satu pihak, namun dapat menilai secara obyektif sehingga minimal dapat mencapai rasa keadilan. Disamping itu juga harus mempertimbangkan keadaan ekonomi masyarakat manakala pemegang hak atas tanah tidak lagi menguasai tanah yang dibebaskan, paling tidak bentuk dan jumlah yang ditetapkan sebagai ganti rugi memberikan harapan yang menjanjikan kehidupan pemegang hak atas tanah akan lebih baik dan tidak menjadikan kehidupannya lebih buruk dari keadaan sebelumnya, karena pada umumnya korban penggusuran pengadaan tanah ini belum dapat merasakan keadilan sesuai dengan pengorbanannya atau obyek yang dimiliki digunakan untuk kepentingan umum.

Tanah yang diperlukan pemerintah untuk kepentingan umum memerlukan jaminan, baik bagi pihak warga Negara maupun bagi pihak pemerintah, karena pada dasarnya persoalan tanah merupakan persoalan rumit, tanah merupakan suatu kebutuhan potensial dalam pembangunan. Bagi masyarakat atau pemegang hak atas tanah hubungan hukum dengan tanah adalah merupakan hubungan hukum yang penting sehingga apabila benarbenar diperlukan. Penggusuran hak atau penglihan hak tersebut menjadi kepentingan umum hendaknya dilakukan dengan hati-hati dan dengan penuh rasa keadilan sehingga pencabutan hak atas tanah adalah menjadi jalan terakhir untuk memperoleh tanah demi pembangunan untuk kepentingan umum. Namun yang paling terpenting adalah adanya kesepakatan sehingga tidak ada pemegang hak atas tanah merasa dirugikan dan dipaksakan kehendaknya untuk melepaskan tanahnya.

Pelepasan hak atas tanah dapat diserahkan secara sukarela atau ada ganti rugi kepada pemilik tanah. Penyerahan secara sukarela atau dengan ganti rugi inilah yang disebut melepaskan hak, dalam prakteknya istilah sukarela itu tidak murni lagi, sebab ada unsur ganti rugi. ${ }^{18}$ Pemberian ganti kerugian dapat diberikan dalam bentuk uang, tanah pengganti, pemukiman kembali, kepemilikan saham, bentuk lain yang disetujui para pihak, namun yang menjadi persoalan adalah jika pemegang hak atas tidak menyetujui segala bentuk dan jenis ganti kerugian dan pada intinya adalah tidak mau melakukan pelepasan hak walaupun ada ganti kerugian. Maka dalam hal ini pemegang hak atas tanah dapat menolak dan mengajukan keberatan kepada pengadilan negeri setempat dalam waktu paling lama 14 (empat belas) hari kerja setelah musyawarah penetapan ganti rugi dilakukan.

Setelah pengadilan negeri memutuskan bentuk dan jenis ganti kerugian tetapi pemegang hak atas tanah tetap menolak ganti kerugian tersebut maka pemegang hak atas tanah dapat mengajukan kasasi kepada Mahkamah Agung Republik Indonesia. Dengan demikian maka putusan pengadilan negeri / Mahkamah Agung yang telah memperoleh kekuatan hukum tetap menjadi dasar pembayaran ganti kerugian kepada pihak yang mengajukan keberatan artinya bahwa dalam proses dipengadilan ini pola musyawarah dalam penetapan ganti kerugian tidaklah berhasil mencapai kesepakatan.

\section{b. Penyelesaian Sengketa Ganti Kerugian Dalam Pengadaan Tanah Bagi Pembangunan Jalan Untuk Kepentingan Umum melalui Lembaga Pengadilan}

Pengadilan mempunyai kewenangan dalam memutuskan jumlah dan bentuk kerugian

17 Laturette, A. I. (2016), "Penyelesaian Sengketa Hak atas Tanah Masyarakat Hukum Adat", SASI, 22 (2): 52-66, h. 66.

${ }^{18}$ Hallauw, D. K., Matuankotta, J. K., \& Uktolseja, N. (2020), “Analisis Hukum Surat Pelepasan Hak Atas Tanah Adat (Dati) Di Kota Ambon”, SASI, 26 (1): 111-118, h. 114. 
diberikan kepada pemegang hak atas tanah yang haknya terkena pengadaan tanah bagi pembangunan untuk kepentingan umum. Pengadilan negeri memeriksa keberatan ganti kerugain paling lama 30 hari kerja, terhitung sejak di terimanya pengajuan keberatan, sebagai pertimbangan bagi hakim dalam memutuskan keputusan atas besaran ganti kerugian maka pihak yang berkepentingan dapat mengajukan atau menghadirkan saksi ahli di bidang penilaian untuk didengar pendapatnya sebagai pembanding atas penilain ganti kerugian sebagaimana disebutkan pada penjelasan Pasal 38 ayat (2) yang menyebutkan :

"Sebagai pertimbangan dalam memutus putusan atau besaran ganti kerugian, pihak yang berkepentingan dapat menghadirkan saksi ahli dibidang penilaian untuk didengar pendapatnya sebagai pembanding atas penilaian ganti kerugian”.

Pola penyelesaian sengketa pada aturan sebelumnya yaitu peraturan Presiden Nomor 65 Tahun 2006 bahwa jika ada pihak yang keberatan atau tidak menerima besar dan bentuk ganti kerugian karena dianggap tidak layak maka hal utama yang dilakukan adalah keberatan kepada gubernur, jika setelah ada penetapan dari gubernur dan pemegang hak atas tanah tetap tidak menerima bentuk dan besar ganti kerugian tersebut maka pemilik tanah dapat mengajukan banding kepada pengadilan tinggi agar pengadilan itulah yang menetapkan ganti kerugian tersebut, dengan hukum acara khusus dalam waktu singkat. Namun penyelesaian ganti kerugian tersebut tidak menunda jalannya pencabutan hak, artinya setelah ada keputusan presiden tentang pencabutan hak itu, maka tanah dan benda-benda yang bersangkutan dapat segera tanpa menunggu keputusan pengadilan negeri mengenai sengketa tersebut.

Sikap memaksa terhadap masyarakat tanpa menghargai pemegang hak atas tanah dirasakan secara jelas oleh masyarakat, karena upaya banding yang dilakukan tidaklah berarti apa-apa manakala pencabutan hak dilakukan oleh Negara, perlindungan yang diberikan Negara sungguh terbatas sehingga kegiatan pembangunan untuk kepentingan umum tidak mungkin masyarakat dapat melawan dan memungkinkan akan timbul konflik secara fisik dan non fisik, dalam hal ini tampaknya interpretasi terhadap asas fungsi sosial hak atas tanah, disamping mengandung makna bahwa hak atas tanah itu harus sesuai dengan sifat dan tujuan haknya, sehingga bermanfaat bagi si pemegang hak dan masyarakat secara umum berarti bahwa harus terdapat keseimbangan antara kepentingan perseorangan dengan kepentingan umum, bahwa kepentingan perorangan itu diakui dan dihormati dalam rangka pelaksanaan kepentingan masyarakat secara keseluruhan dan menemukan keseimbangan antara pemegang hak atas tanah dengan kepentingan pemerintah tidak mudah untuk di temukan makna yang sebenarnya, namun yang paling terpenting adalah bisa mencapai kesepakatan tanpa ada penyelesaian di pengadilan.

Pengadilan dalam memutuskan ganti kerugian agar terasa adil bagi pemegang hak atas tanah. Kriteria tertentu diterapkan secara obyektif dengan standar yang telah ditetapkan terlebih dahulu, juga sebagai tambahan pemegang hak perlu mengetahui dasar penentuan besar kecil ganti kerugian yang diterima.

\section{c. Penitipan Ganti Kerugian Dalam Pengadaan Tanah}

Undang-Undang No 2 tahun 2012 mengenal ganti kerugian non fisik, istilah konsinyasi juga tidak dikenal dalam undang-undang ini namun istilah yang digunakan adalah penitipan ganti kerugian di pengadilan. Didalam UU Nomor 2 Tahun 2012 Pasal 41 ayat 1 dan 3 menyebutkan:

(1). Ganti kerugian diberikan kepada pihak yang berhak berdasarkan hasil penilaian yang ditetapkan dalam musyawarah sebagaimana dimaksud dalam pasal 37 ayat (2) dan/atau putusan pengadilan negeri/mahkamah agung sebagaimana dimaksud dalam 
Pasal 38 ayat (5)

(3) Bukti sebagaimana dimaksud pada ayat (2) huruf b merupakan satu-satunya alat bukti yang sah menurut hukum dan tidak dapat diganggu gugat dikemudian hari.

Penitipan ganti kerugian yang dilakukan di pengadilan negeri setempat dilakukan dalam hal-hal sebagai berikut:

1) Pihak yang berhak menolak bentuk dan/atau besarnya ganti kerugian berdasarkan hasil musyawarah atau putusan pengadilan negeri/Mahkamah Agung ganti kerugian di titip di pengadilan setempat

2) Pihak yang berhak menerima ganti kerugian tidak diketahui keberadaannya atau

3) Objek pengadaan tanah yang akan diberikan ganti kerugian, sedang menjadi objek perkara di pengadilan, masih dipersengketakan kepemilikannya, diletakan sita oleh pejabat yang berwenang atau menjadi jaminan di bank.

Pada saat pelaksanaan pemberian ganti kerugian atau di titip di pengadilan negeri, kepemilikan atau hak atas tanah dari pihak yang berhak menjadi hapus dan alat bukti haknya dinyatakan tidak berlaku dan tanahnya adalah tanah yang dikuasai langsung oleh Negara, sebagaimana disebutkan dalam Pasal 43 UU Nomor 2 tahun 2012 yang berbunyi :

"Pada saat pelaksanaan pemberian ganti kerugian dan pelepasan hak sebagaimana dimaksud dalam Pasal 41 ayat (2) huruf a telah dilaksanakan atau pemberian ganti kerugian sudah dititipkan di pengadilan negeri sebagaimana dimaksud dalam Pasal 42 ayat (1), Kepemilikan atau hak atas tanah dari pihak yang berhak menjadi hapus dan alat bukti haknya dinyatakan tidak berlaku dan tanahnya menjadi tanah yang dikuasai langsung oleh Negara".

Penitipan ganti kerugian ini adalah jelas salah satu bentuk dari pemaksaan terhadap masyarakat untuk melepaskan haknya, jiwa dari undang-undang ini berkaitan erat dengan pencabutan hak atas tanah. Hanya prosedur pencabutan hak yang berbeda, dengan demikian maka penyelesaian sengketa yang diterapkan dalam penetapan ganti kerugian pengadaan tanah bagi pembangunan untuk kepentingan umum adalah dengan menggunakan dua pola penyelesaian yaitu secara litigasi dan nonlitigasi.

1) Penyelesaian secara non litigasi dalam pengadaan tanah untuk kepentingan umum dalam Undang-Undang Nomor 2 tahun 2012 meliputi: dilakukannya musyawarah dalam penetapan lokasi pembangunan dan musyawarah penetapan ganti kerugian, dilakukannya upaya keberatan yang diajukan kepada panitia pengadaan tanah dan instansi yang memerlukan tanah.

2) Pola penyelesaian sengketa dalam pengadaan tanah bagi pembangunan untuk kepentingan umum adalah dengan pola atau jalur litigasi / melalui lembaga pengadilan dalam hal ini meliputi: keberatan yang dilakukan pemegang hak atas tanah terhadap penetapan lokasi pembangunan untuk kepentingan umum ke pengadilan tata usaha Negara, mengajukan keberatan kepada pengadilan negeri oleh pemegang hak atas tanah karena menolak jenis dan besar nilai ganti kerugian yang di tetapkan oleh panitia pengadaan tanah.

Menurut penulis bahwa penyelesaian sengketa dalam pengadaan tanah yang disebabkan tidak diterimanya penetapan lokasi pembangunan dan pemberian besar nilai ganti kerugian, maka pola non litigasi yang digunakan adalah lebih kepada penyelesaian yang bersifat negosiasi karena tidak melibatkan pihak ketiga sebagai mediator, dalam negosiasi ganti kerugian terhadap objek pengadaan tanah yang dilakukan posisi pemegang hak atas tanah adalah lemah karena dapat dilakukan pemaksaan untuk melepaskan hak atas tanah, namun seharusnya ada pihak ketiga yang bersifat netral sebagai mediasi dalam penetapan 
lokasi pembangunan maupun dalam penetapan ganti kerugian (proses mediator). Jika dalam hal belum dapat dicapai kata sepakat bisa dilakukan dengan Arbitarase sampai dengan ajudikasi.

Demikian pada tahap negosiasi adalah tahap yang penting, maka negosiasi dilakukan dalam bentuk musyawarah adalah salah satu strategi penting untuk menyelesaikan sengketa, agar negosiasi bisa berjalan dan mudah mendapatkan kesepakatan maka keterampilan komunikasi dan wawasan para pihak sangat menentukan terutama dalam menyampaikan kepentingan dan keinginan diri atau pihak yang lain. ${ }^{19}$

Penyelesaian sengketa dalam pengadaan tanah hendaknya dilakukan dengan semaksimal mungkin melalui jalur non litigasi atau penyelesaian di luar pengadilan karena memang dalam hukum tanah nasional juga berdasarkan hukum adat. Pada prinsipnya hukum adat berbeda dengan masyarakat modern, penyelesaian sengketa dalam masyarakat hukum adat didasarkan pada pandangan hidup yang dianut oleh masyarakat itu sendiri. ${ }^{20}$ Pandangan hidup masyarakat adat bertumpu pada filsafat eksistensi yaitu filsafat manusia yang mengajarkan pada hidup rukun dan bersama. Maka setidaknya upaya paksaan pelepasan hak dalam pengadaan tanah harus dihindari dengan tetap mengedepankan kebersamaan dan mencegah terjadi konflik pertanahan antara pemerintah dan pemegang hak atas tanah.

\section{P E N U T U P}

Berdasarkan uraian yang disebutkan di atas, dapat disimpulkan bahwa pengadaan tanah untuk kepentingan umum mencangkup beberapa tahapan meliputi Tahap Perencanaan Pengadaan Tanah, Tahap Persiapan Pengadaan, Tahapan Pelaksanaan Pengadaan Tanah berupa Inventarisasi dan Identifikasi Penguasaan, Pemilikan, Penggunaan dan Pemanfaatan tanah, Melakukan Penilaian Ganti Rugi, Melakukan Musyawarah Penetapan Ganti Rugi, Melakukan Penyerahan Hasil Pengadaan Tanah. Penyelesaian sengketa pengadaan tanah untuk kepentingan umum melalui musyawarah dalam penetapan ganti rugi, melalui lembaga pengadilan dan penitipan ganti kerugian dalam pengadaan tanah melalui pengadilan.

\section{DAFTAR PUSTAKA}

\section{Jurnal}

[1] Hetharie, Y. (2019). Perjanjian Nominee sebagai Sarana Penguasaan Hak Milik atas Tanah oleh Warga Negara Asing Menurut Kitab Undang-Undang Hukum Perdata. SASI, 25 (1): 27-36, h. 27.

[2] Hallauw, D. K., Matuankotta, J. K., \& Uktolseja, N. (2020). Analisis Hukum Surat Pelepasan Hak Atas Tanah Adat (Dati) Di Kota Ambon. SASI, 26 (1): 111-118, h. 114.

[3] Kasenda, D. GG. (2015). Ganti Rugi Dalam Pengadaan Tanah Untuk Kepentingan Umum. Jurnal Morality, 2 (2): Tanpa Halaman

[4] Laturette, A. I. (2016). Penyelesaian Sengketa Hak Atas Tanah Masyarakat Hukum Adat. SASI, 22 (2): 52-66, h. 66.

[5] Matuankotta, J. K. (2020). Pengakuan dan Perlindungan Hukum Terhadap Eksistensi Pemerintahan Adat. SASI, 26 (2): 188-200, h.193.

19 Abbas, S. (2011), Mediasi Dalam Hukum Syari'ah, Hukum Adat Dan Hukum Nasional, cetakan 2, Jakarta: Media Grafika, h.10

20 Ibid, h. 237. 
[6] Santoso, U. (2016). Penyelesaian Sengketa Dalam Pengadaan Tanah Untuk Kepentingan Umum. PERSPEKTIF, XXI (3): 188-198, h. 188.

[7] Subekti, R. (2016). Kebijakan Pemberian Ganti Kerugian dalam Pengadaan Tanah Bagi Pembangunan untuk Kepentingan Umum. Yustisia, 5 (2): 376-394, h. 387.

[8] Suntoro, A. (2019). Penilaian Ganti Kerugian Dalam Pengadaan Tanah untuk Kepentingan Umum: Perspektif HAM. BHUMI: Jurnal Agraria dan Pertanahan, 5 (1): 13-25, DOI: http://dx.doi.org/10.31292/jb.v5i1.316, h. 13.

[9] Saija, R., Letsoin, F. X. R. V., Akyuwen, R. J., \& Radjawane, P. (2020). Status Kepemilikan Hak atas Tanah Adat Marga dalam Kebijakan Penataan Aset Reforma Agraria di Kabupaten Maluku Tenggara. SASI, 26 (1): 99-100, h. 107.

[10] Uktolseja, N., \& Radjawane, P. (2019).Tinjauan Juridis Perkembangan Tanah-Tanah Adat (Dahulu, Kini dan Akan Datang). SASI, 25 (1): 13-26, h. 25.

\section{Buku}

[11] Abbas, S. (2011), Mediasi Dalam Hukum Syari'ah, Hukum Adat Dan Hukum Nasional, Jakarta: Media Grafika.

[12] Bakri, M. (2007), Hak Menguasai Tanah Oleh Negara (Paradigma Baru Untuk Reformasi Agraria), Yogyakarta: Citra Media.

[13] Hartanto, A. (2015). Panduan Lengkap Hukum Praktis: Kepemilikan Tanah, Jakarta: Penerbit Laksbang Justitia.

[14] Limbong, B. (2015). Pengadaan Tanah Untuk Pembangunan Fasilitas Umum, Jakarta Selatan: Margareta Pustaka.

[15] Marsoem, S. Cs, (2015). Pedoman Lengkap Ganti Untung Pengadaan Tanah, Jakarta: Penerbit Renebook.

[16] Soekanto S, dan Mamudji, Sri. (2001). Penelitian Hukum Normatif (Suatu Tinjauan Singkat), Jakarta: Rajawali Pers. 